\title{
Determination of time dependent antibacterial activities of curcumin, carvacrol and styrax liquidus on Salmonella Enteritidis
}

\author{
Erhan KEYVAN ${ }^{1, a, ®}$, Hidayet TUTUN ${ }^{2, b}$, Hatice Ahu KAHRAMAN ${ }^{1, c}$, Erdi ŞEN $^{1, d}$, \\ Ahu DEMIRTAŞ ${ }^{3, e}$, Soner DÖNMEZ ${ }^{4, f}$, Ali Özhan AKYÜZ ${ }^{5, g}$
}

\begin{abstract}
${ }^{1}$ Burdur Mehmet Akif Ersoy University, Faculty of Veterinary Medicine, Department of Food Hygiene and Technology, Burdur, Türkiye; ${ }^{2}$ Burdur Mehmet Akif Ersoy University, Faculty of Veterinary Medicine, Department of Pharmacology and Toxicology Burdur, Türkiye; ${ }^{3}$ Burdur Mehmet Akif Ersoy University, Faculty of Veterinary Medicine, Department of Physiology Burdur, Türkiye; ${ }^{4}$ Burdur Mehmet Akif Ersoy University, Bucak School of Health, Burdur, Türkiye; ${ }^{5}$ Burdur Mehmet Akif Ersoy University, Bucak Emin Gulmez Technical Sciences Vocational Higher School, Department of Electronics and Automation. Burdur, Türkiye aORCID: 0000-0002-2981-437X, ' ORCID: 0000-0001-9512-8637, ${ }^{\mathrm{c} O R C I D: 0000-0001-6600-239 X,}$ dORCID: 0000-0002-5140-3833, '्,ORCID: 0000-0003-2942-6243, fORCID: 0000-0003-0328-6481, gORCID: 0000-0001-9265-7293
\end{abstract}

\author{
$\triangle$ Corresponding author: erhankeyvan@gmail.com \\ Received date: 07.04.2021 - Accepted date: 06.07.2021
}

\begin{abstract}
Salmonella Enteritidis is amongst the most common causes of foodborne salmonellosis. Multi-drug resistant Salmonella strains has been associated with treatment failures. Plant-derived phytochemicals may be an alternative to antibiotics in combating these bacteria. The purpose of this study is to investigate the antibacterial activity of curcumin, carvacrol and styrax liquidus on $S$. Enteritidis and $S$. Enteritidis PT4. Minimum inhibitory concentration (MIC) values of these substances were detected at 1.5, 3, 7.5 and $24 \mathrm{~h}$ by broth microdilution method to evaluate their time-dependent antibacterial activities. The findings of the present study showed that MIC values of carvacrol, curcumin and styrax liquids for both $S$. Enteritidis and $S$. Enteritidis PT4 were $125.0 \mu \mathrm{g} / \mathrm{mL}$, $132.5 \mu \mathrm{g} / \mathrm{mL}, 31.3 \mathrm{mg} / \mathrm{mL}$ for $24 \mathrm{~h}$, respectively. Also, a time-dependent change was observed in the MIC values of curcumin. Carvacrol, curcumin and styrax liquidus can be used to provide antimicrobial effect on $S$. Enteritidis and $S$. Enteritidis PT4 in food applications, taking into account the MIC values and contact times.
\end{abstract}

Keywords: Carvacrol, curcumin, MIC, Salmonella Enteritidis, styrax liquidus.

\section{Kurkumin, karvakrol ve sığla yağının Salmonella Enteritidis üzerine zamana bağlı antibakteriyel aktivitesinin belirlenmesi}

Özet: Salmonella Enteritidis, gıda kaynaklı salmonellozisin en yaygın nedenleri arasındadır. Çoklu antibiyotiklere dirençli Salmonella suşları, tedavide başarısızlıklara neden olmaktadır. Bitki kaynaklı fitokimyasallar, bu bakterilerle mücadelede antibiyotiklere bir alternatif olabilir. Bu çalışmanın amacı, kurkumin, karvakrol ve sığla yağının $S$. Enteritidis ve $S$. Enteritidis PT4 üzerindeki antibakteriyel aktivitesini araştırmaktır. Bu maddelerin minimum inhibitör konsantrasyon (MIK) değerleri, zamana bağlı antibakteriyel aktivitelerini değerlendirmek için broth mikrodilüsyon yöntemi ile 1,5, 3, 7,5 ve 24. saatlerde belirlenmiştir. Çalışmanın bulgularında, hem $S$. Enteritidis hem de $S$. Enteritidis PT4 için karvakrol, kurkumin ve sığla yağının MíK değerlerinin 24 saat boyunca sırasıyla $125,0 \mu \mathrm{g} / \mathrm{mL}, 132,5 \mu \mathrm{g} / \mathrm{mL}, 31,3 \mathrm{mg} / \mathrm{mL}$ olarak tespit edilmiştir. Ayrıca, kurkuminin MiK değerlerinde zamana bağl1 bir değişiklik de görülmüştür. MiK değerleri ve temas süreleri dikkate alındığında karvakrol, kurkumin ve sığla yağının, gıda uygulamalarında $S$. Enteritidis ve $S$. Enteritidis PT4 üzerinde antimikrobiyal etki sağlamak için kullanılabileceği sonucuna varılmıştır.

Anahtar sözcükler: Karvakrol, kurkumin, MiK, Salmonella Enteritidis, sığla yağı.

\section{Introduction}

Foodborne diseases resulting from ingestion of contaminated food by a defined list of microbes, parasites and chemicals are cause of morbidity and mortality worldwide (4). The World Health Organization (WHO) estimated that they affect 600 million people and 420,000 deaths occur annually in 2010, resulting in the loss of 33 million healthy life years. Salmonella species are responsible for a quarter of 550 million diarrheal illness worldwide each year (48). It is estimated that 155,000 
deaths occur in the world each year due to bacteria Salmonella spp. (10). Salmonella spp. reside in the gastrointestinal tract of different domestic animals and are usually present in stool exerted by healthy animals and may contaminate fruits and vegetables and foods of animal origin $(27,46)$. Thus, Salmonella can be spread between human and animals, and cause disease. Salmonella Enteritidis and $S$. Enteritidis PT4 are most commonly isolated serotypes from foods of animal origin and are important causes of infections associated with these foods in humans $(18,47)$.

Antimicrobials play an important role in the control of bacterial foodborne infections. However, misuse and overuse of antibiotics in the management of human and animal diseases encourage the bacteria to develop resistance. The rapid emergence of antimicrobial resistance has been a global problem for managing the health care of people and animals (30). It has been reported that there is a link between the use of antimicrobials in livestock and the emergence of antimicrobial resistance in pathogenic bacteria $(13,27)$. Spread of resistant bacteria from animals to humans may occur through foods, environment, or direct interaction with animals and leads to great challenges in infection control (19). The emergence and spread of resistance to multiple antibiotics as well as a lack of new drug development by the pharmaceutical industry has led to an increase interest in medicinal plants. Various crude extracts or individual compounds and essential oils of the medicinal plants could serve as an alternative source of new antimicrobials due to a broad range of secondary metabolites $(15,23)$.

Several plant-derived compounds including carvacrol and curcumin have attracted the attention of the scientific community for their antimicrobial properties. Carvacrol, the main active ingredient of essential oils, are known by its broad-spectrum antimicrobial and antioxidant activities $(6,11,33)$. Curcumin, a polyphenolic natural ingredient derived from Curcuma longa roots, is known to exert antimicrobial activity against a variety of bacterial species $(2,26)$. Styrax liquidus, locally named as "sığla yağı" is a resinous exudate (balsam) obtained from the incision trunk of Liquidambar orientalis Miller tree which is an endemic species in Türkiye. It has been used for the treatment of peptic ulcer in Turkish folk medicine (16). Styrax liquidus consists of resin, essential oils, styrene and cinnamic acid $(16,20)$. There are few studies investigated the antibacterial activity of styrax liquidus (35).

There is no research investigating antibacterial activity of these substances, becoming popular in the world and Türkiye, on Salmonella species. Hence, it was aimed to investigate of antibacterial activities of carvacrol, curcumin and styrax liquidus on $S$. Enteritidis and $S$. Enteritidis PT4 at different time parameters $(1.5,3,7.5$ and $24 \mathrm{~h}$ ) in the present study.

\section{Materials and Methods}

Compounds and Materials: Carvacrol (Sigma, 282197) and curcumin (C1386, Sigma, $\geq 65 \%$ ) were purchased from Sigma-Aldrich (Madrid, Spain), Styrax liquidus (Sweetgum) was purchased from local producers. Carvacrol and curcumin were dissolved in dimethyl sulfoxide (DMSO, Aldrich, 99.5\%) to prepare stock solutions of $500 \mathrm{mg} / \mathrm{mL}$ for carvacrol $(\mathrm{w} / \mathrm{v}, 1 / 1)$ and 3.6 $\mathrm{mg} / \mathrm{mL}$ for curcumin (curcumin/DMSO, w/v, $8.33 \mathrm{mg} / 1.5$ $\mathrm{mL}$ ). Sweetgum was dissolved in absolute ethanol (Sigma, $1.02428)$ to prepare stock solution of $500 \mathrm{mg} / \mathrm{mL}(\mathrm{v} / \mathrm{v}$, 1/1). Mueller Hinton broth (MHB, CM0405) and Mueller Hinton agar (MHA, CM0337) were purchased from Oxoid (Oxoid Ltd., Basingstoke, England).

Bacterial Strain: American Type Culture Collection (ATCC) standard S. Enteritidis (ATCC: 13076) and National Collection of Type Cultures standard $S$. Enteritidis PT4 (NCTC: 13349) were used for the screening antibacterial activities of sweetgum, carvacrol and curcumin. The strains were incubated at $37^{\circ} \mathrm{C}$ for 24 hours to evaluate the antibacterial activity of plant-derived compounds.

Evaluation of Antibacterial Activity: The MIC values of carvacrol, curcumin and styrax liquidus against $S$. Enteritidis and $S$. Enteritidis PT4 were determined according to the microdilution method recommended by the Clinical and Laboratory Standards Institute (CLSI) (8). Briefly, the MICs of the carvacrol, curcumin and styrax liquidus were investigated at eight different concentrations ranged from $7.813 \mu \mathrm{g} / \mathrm{mL}$ to $1000 \mu \mathrm{g} / \mathrm{mL}$, $5.07 \mu \mathrm{g} / \mathrm{mL}$ to $650 \mu \mathrm{g} / \mathrm{mL}$ and $1.95 \mathrm{mg} / \mathrm{mL}$ to $250 \mathrm{mg} / \mathrm{mL}$, respectively. Serial 2-fold dilutions of carvacrol, curcumin and styrax liquidus were prepared in MHB. Two hundred microliters of each different concentrations of carvacrol, curcumin and styrax liquidus were added into the wells of a 96-well plate as separate study groups. Then, $20 \mu \mathrm{L}$ containing $0.5 \mathrm{McF}$ arland cell $/ \mathrm{mL}$ bacteria was added each well (9). The well plates were incubated at $37^{\circ} \mathrm{C}$ under aerobic conditions for $24 \mathrm{~h}$. The MIC was defined as the lowest concentration of the substance where bacterial growth was not detected. All trial groups were carried out in triplicate. Absorbance was measured at 600 $\mathrm{nm}$ (OD600) to monitor the microbial growth by using a microplate reader (Epoch, BioTek, USA) at 1.5, 3, 7.5 and $24 \mathrm{~h}$ of incubation. In the evaluation of optical density values, the average of the trials of each bacterium in triplicate were taken. It was found by taking the difference of the values given as "blank" from the reproductive optical density values of the relevant bacteria. The lowest substance concentration with no microbial growth and OD600 value of $\leq 0.1$ was accepted as the MIC value (21). The effects of solvents used on bacterial growth was examined using the MIC method at the final concentration of solvents in each well. It was observed that the final concentration of the solvents in each well did not show any inhibitory effect against bacterial growth. 


\section{Results}

The broth microdilution test was carried out to assess the antimicrobial activities of carvacrol, curcumin and styrax liquidus on $S$. Enteritidis and $S$. Enteritidis PT4 at 1.5, 3, 7.5 and $24 \mathrm{~h}$. All MIC values are given in Table 1. Since bacterial growth could not be observed clearly, the MIC values of curcumin and styrax liquidus at 1.5 and $3 \mathrm{~h}$ could not be determined. Similarly, the MIC values of carvacrol could not be determined at $1.5 \mathrm{~h}$. According to the results of the study, although there was no timedependent change in the MIC values of carvacrol and styrax liquidus, a time-dependent change was observed in the MIC values of curcumin. Curcumin exhibited the excellent antimicrobial activity against these bacteria in
$24 \mathrm{~h}$ of treatment. After $7.5 \mathrm{~h}$ of application, the MIC value of curcumin against $S$. Enteritidis was $650 \mu \mathrm{g} / \mathrm{mL}$ while it was $325 \mu \mathrm{g} / \mathrm{mL}$ against $S$. Enteritidis PT4. However, in 24-h application, curcumin presented similar MIC values against both bacteria (Figure 1).

According to the MIC values, Although $S$. Enteritidis and $S$. Enteritidis PT4 were found to be less susceptible to styrax liquidus (MIC value: $31.3 \mathrm{mg} / \mathrm{mL}$ ), they were more susceptible to carvacrol $(125 \mu \mathrm{g} / \mathrm{mL})$. In the wells treated with curcumin, optical densities up to 0.25 (OD600 nm) were observed in the measurements made at 1.5 and $3 \mathrm{~h}$. In this study, the solvents (Ethanol and DMSO) used to dissolve the substances did not show any antibacterial activity at the application doses.
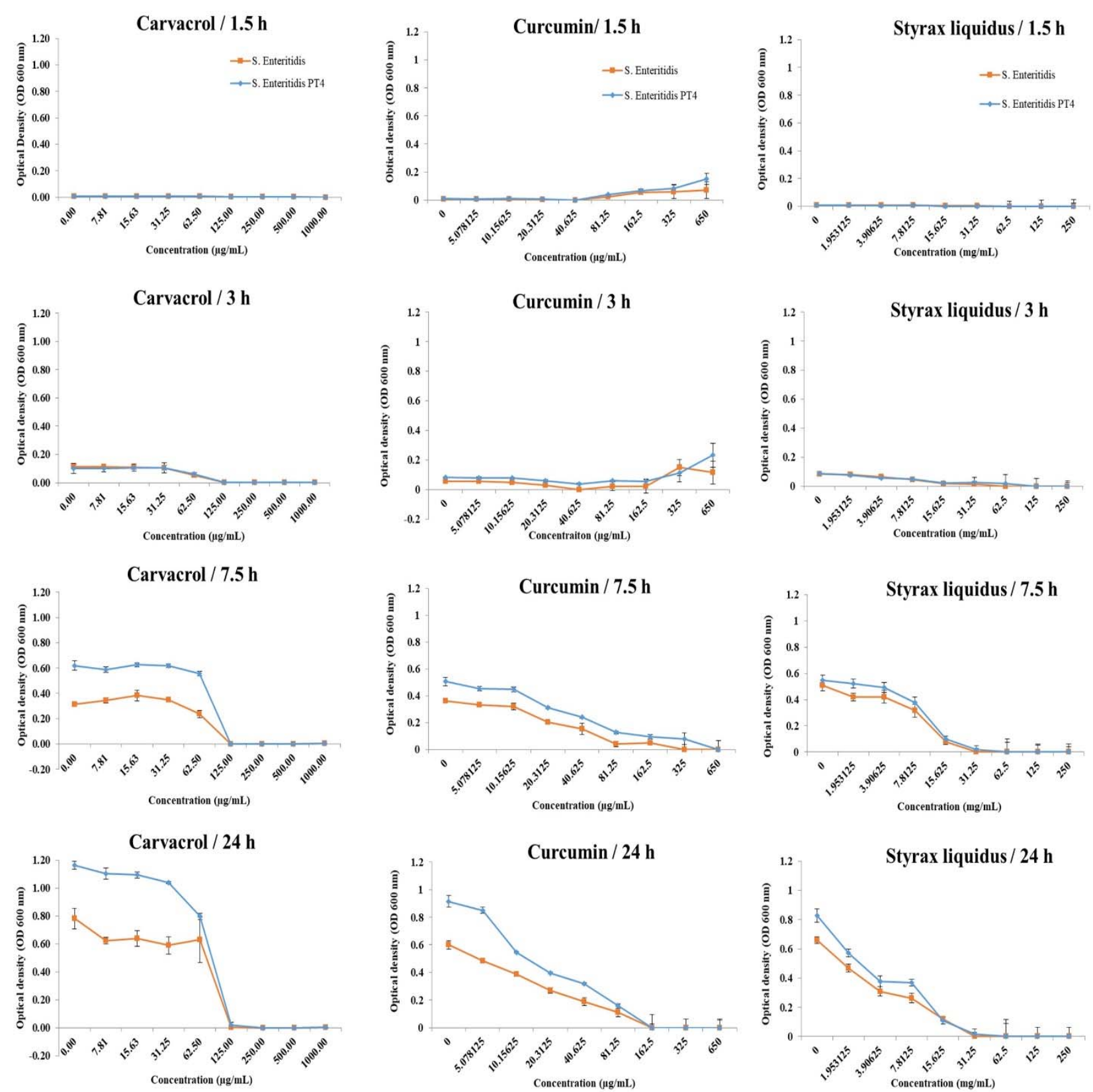

Figure 1. The growth rates of $S$. Enteritidis and $S$. Enteritidis PT4 according to exposure time and concentration of substances. 
Table 1. MIC values of Carvacrol, Curcumin and Styrax Liquidus at $37^{\circ} \mathrm{C}$ for $1.5,3,7.5$ and $24 \mathrm{~h}$.

\begin{tabular}{|c|c|c|c|c|c|c|c|}
\hline \multirow[t]{2}{*}{ Times } & \multirow[t]{2}{*}{ Trials } & \multicolumn{2}{|c|}{$\operatorname{Carvacrol}(\mu \mathrm{g} / \mathrm{mL})$} & \multicolumn{2}{|c|}{ Curcumin $(\mu \mathrm{g} / \mathrm{mL})$} & \multicolumn{2}{|c|}{ Styrax Liquidus (mg/mL) } \\
\hline & & S. Enteritidis & $\begin{array}{c}\text { S. Enteritidis } \\
\text { PT4 }\end{array}$ & S. Enteritidis & $\begin{array}{c}\text { S. Enteritidis } \\
\text { PT4 }\end{array}$ & S. Enteritidis & $\begin{array}{c}\text { S. Enteritidis } \\
\text { PT4 }\end{array}$ \\
\hline \multirow[t]{3}{*}{$1.5 \mathrm{~h}$} & 1 & $*$ & $*$ & $*$ & $*$ & $*$ & $*$ \\
\hline & 2 & $*$ & $*$ & $*$ & $*$ & $*$ & $*$ \\
\hline & 3 & $*$ & $*$ & $*$ & $*$ & $*$ & $*$ \\
\hline \multirow[t]{3}{*}{$3 \mathbf{h}$} & 1 & 125.0 & 125.0 & $*$ & $*$ & $*$ & $*$ \\
\hline & 2 & 125.0 & 125.0 & $*$ & $*$ & $*$ & $*$ \\
\hline & 3 & 125.0 & 125.0 & $*$ & $*$ & $*$ & $*$ \\
\hline \multirow[t]{3}{*}{$7.5 \mathrm{~h}$} & 1 & 125.0 & 125.0 & 650.0 & 325 & 31.3 & 31.3 \\
\hline & 2 & 125.0 & 125.0 & 650.0 & 325 & 31.3 & 31.3 \\
\hline & 3 & 125.0 & 125.0 & 650.0 & 325 & 31.3 & 31.3 \\
\hline \multirow[t]{3}{*}{$24 \mathrm{~h}$} & 1 & 125.0 & 125.0 & 162.5 & 162.5 & 31.3 & 31.3 \\
\hline & 2 & 125.0 & 125.0 & 162.5 & 162.5 & 31.3 & 31.3 \\
\hline & 3 & 125.0 & 125.0 & 162.5 & 162.5 & 31.3 & 31.3 \\
\hline
\end{tabular}

\section{Discussion and Conclusion}

Antibacterial (antibiotic) drug resistance is a growing global problem and the number of new approved drugs is declining. Hence, the need for new antimicrobials becomes more pressing in bacterial infections $(22,31)$. Plant extracts and essential oils are known as a good source of antimicrobial substance effective on foodborne pathogens as they have antibacterial, antifungal, antiparasitic and antiviral properties $(40,41)$. There is a great number of natural compounds isolated from plants, a part of them has an important role in food, cosmetics, sanitary fields and oral-dental treatments $(32,37)$. Recently, there has been an increased interest in the assessment of the antimicrobial potential of natural plant compounds such as curcumin and carvacrol against pathogen bacteria $(7,23,24)$.

Carvacrol has been reported as antibacterial agent. However, the reported values of MICs are widely divergent. Several studies have reported that carvacrol shows antibacterial activity against $S$. Enteritidis with MIC values ranging 156 to $331 \mu \mathrm{g} / \mathrm{mL}(5,6,11,33)$. The result of this study showed a MIC value for carvacrol of $125 \mu \mathrm{g} / \mathrm{mL}$ for $S$. Enteritidis and $S$. Enteritidis PT4. The MIC and above concentrations of carvacrol inhibited the growth of $S$. Enteritidis and $S$. Enteritidis PT4 at 3, 7.5 and $24 \mathrm{~h}$. The antibacterial activity of carvacrol has been attributed to its hydrophobic property that influences the fluidity and permeability of the bacterial cell membrane by changing the lipid fraction (34). Also, carvacrol leads to the leakage and loss of ATP from bacterial cells (44, 45). The membrane fluidity has been found to play an important role in the bactericidal activity of the carvacrol against Bacillus cereus (44). In this study, at concentration of $125 \mu \mathrm{g} / \mathrm{mL}$ and above, total inhibition of the growth was observed and carvacrol may be bactericidal towards
$S$. Enteritidis and $S$. Enteritidis PT4. The bactericidal activity against these bacteria may be due to affecting the fluidity and permeability of bacterial cell membrane.

Curcumin, naturally found as a constituent of dietary species called turmeric (Curcuma longa), has been the subject of intensive investigation on its various activities including antiviral, antibacterial and anticancer (39). Contrary of these, there is an evidence that curcumin increases the resistance of $S$. Typhimurium resistance to antimicrobial agents such as antimicrobial peptides, reactive oxygen and nitrogen species. The tolerance developed may be attributed to the up-regulation of genes involved in resistance to some antimicrobial peptides and genes with antioxidant function (28). Adamczak et al. (1) reported that curcumin exhibit a significantly larger variation in the its antibacterial activity (MICs ranged from 31.25 to $5000 \mu \mathrm{g} / \mathrm{mL}$ against over 100 strains of pathogens belonging to 19 species) and suggested that curcumin can be considered as a promising antibacterial agent but, with a very selective activity. Several studies have reported that curcumin shows strong antimicrobial activity against Gram-positive than Gram-negative bacteria with MIC values ranged from $62.5 \mu \mathrm{g} / \mathrm{mL}$ to 5000 $\mu \mathrm{g} / \mathrm{mL}(1,14,36,38)$. Further detailed studies are needed to investigate its antibacterial activity. There are few studies investigating the antibacterial activity of carvacrol on Salmonella spp. A study reported that MIC value for curcumin were found to be $250 \mu \mathrm{g} / \mathrm{mL}$ for $S$. Typhimurium (36). In the current study, even though curcumin exhibited the excellent antimicrobial activity against both $S$. Enteritidis and $S$. Enteritidis PT4 (MIC value of $125 \mu \mathrm{g} / \mathrm{mL}$ ) in $24 \mathrm{~h}$ exposure, the MIC values of curcumin against $S$. Enteritidis and $S$. Enteritidis PT4 were $650 \mu \mathrm{g} / \mathrm{mL}$ and $325 \mu \mathrm{g} / \mathrm{mL}$, respectively, at $7.5 \mathrm{~h}$ of exposure. As the exposure time of curcumin to these 
bacteria increased, its antibacterial activity strengthened. Curcumin shows it antibacterial activity through various mechanisms, including inhibiting bacterial DNA replication, altering gene expression and disrupting the bacterial cell membrane hence it can affect the cell division and proliferation of bacteria $(1,42)$. Increased antibacterial activity over time in this study might be attributed to its mechanism of action. Also, it was thought that the high OD observed at high concentration of curcumin (325 and $659 \mu \mathrm{g} / \mathrm{mL})$ at 1.5 and $3 \mathrm{~h}$ measurements might be due to its coloring properties, low water solubility and poor chemical stability (25).

Styrax liquidus which is a resinous exudate obtained from the wounded barks of Liquidambar orientalis mainly consists of acid, ester, alcohol, phenolic and volatile compounds. Its main components are cinnamic acid, styracin, styrol, stoyrone, storesinol, storesin, cinnamyl cinnamate, 3-phenylpropyl cinnamate, benzyl cinnamate, styrene, trans cinnamyl alcohol, hydrocinnamyl and vanillin. Its composition may vary widely depending upon a number of factors such as collection site, processing and storage conditions $(3,16)$. It has been used against parasitic infections, for treatment of peptic ulcers and burns, and as antiseptic in Turkish traditional medicine $(12,17,43)$. In an in vitro study investigating antibacterial activity against 20 different strains of bacteria using an agar diffusion method, the results showed that styrax liquidus inhibited completely the growth of 13 bacteria at a $10 \%$ concentration and did not inhibit the growth of any bacteria at a $0.1 \%$ concentration. All treatment concentration ( $10 \%-0.1 \%)$ were inactive against 7 bacteria (35). There is literature on the antimicrobial activity of Styrax liquidus on Salmonella spp. Our study showed that it has an inhibitory effect on $S$. Enteritidis and $S$. Enteritidis PT4 at high concentrations (MIC values of 31.2 $\mathrm{mg} / \mathrm{mL}$ for both). Its antimicrobial activity may be attributed to the presence of substances with antimicrobial activity, such as cinnamic acid, in its composition.

In conclusion, carvacrol and curcumin have stronger antibacterial activities than styrax liquidus. While curcumin exhibit its strongest antibacterial effect at $24 \mathrm{~h}$, carvacrol and styrax liquidus showed at $7.5 \mathrm{~h}$. The antibacterial effect of carvacrol and styrax liquidus started at seven and a half hours of administration. Carvacrol and styrax liquidus can be used to provide antimicrobial effect on $S$. Enteritidis and $S$. Enteritidis PT4 in food applications at lower exposure times.

\section{Financial Support}

This work was supported by TUBITAK (The Scientific and Technological Research Council of Türkiye) in the framework of the Career Development Program (3501) (Grant number: 1190672).

\section{Ethical Statement}

This study does not present any ethical concerns.

\section{Conflicts of interest}

The authors declare no conflict of interest.

\section{References}

1. Adamczak A, Ożarowski M, Karpiński TM (2020): Curcumin, a Natural Antimicrobial Agent with StrainSpecific Activity. Pharmaceuticals, 13, 153.

2. Akram M, Shahab-Uddin AA, Usmanghani K, et al (2010): Curcuma longa and curcumin: a review article. Rom J Biol Plant Biol, 55, 65-70.

3. Arslan MB, Şahin HT (2016): Unutulan Bir Orman Ürünü Kaynağı: Anadolu Siğla Ăgacı (Liquidambar Orientalis Miller). Bartın Orman Fakültesi Dergisi, 18, 103-117.

4. Bintsis T (2017): Foodborne pathogens. AIMS Microbiol, 3, 529-563.

5. Božik M, Hovorková P, Klouček P (2018): Antibacterial Effect of Carvacrol and Coconut Oil on Selected Pathogenic Bacteria. Scientia Agriculturae Bohemica, 49, 46-52.

6. Cabarkapa I, Colovic R, Duragic O, et al (2019): Antibiofilm activities of essential oils rich in carvacrol and thymol against Salmonella Enteritidis. Biofouling, 35, 361375.

7. Chouhan S, Sharma K, Guleria S (2017): Antimicrobial Activity of Some Essential Oils-Present Status and Future Perspectives. Medicines, 4, 58.

8. Clinical and Laboratory Sandards Institute (2018): Performance Standards for Antimicrobial Susceptibility Testing. $26^{\text {th }}$ ed Pennsylvania, USA M100S.

9. Demirtas A, Ozturk H, Sudagidan M, et al (2019): Effects of commercial aldehydes from green leaf volatiles (green odour) on rumen microbial population and fermentation profile in an artificial rumen (Rusitec). Anaerobe, 55, 8392.

10. Eng S-K, Pusparajah P, Ab Mutalib N-S, et al (2015): Salmonella: a review on pathogenesis, epidemiology and antibiotic resistance. Frontiers in Life Science, 8, 284-293.

11. Engel JB, Heckler C, Tondo EC, et al (2017): Antimicrobial activity of free and liposome-encapsulated thymol and carvacrol against Salmonella and Staphylococcus aureus adhered to stainless steel. Int J Food Microbiol, 252, 18-23.

12. Erdem Y, Gisho H, Ekrem S, et al (1993): Traditional medicine in Turkey IV. Folk medicine in the Mediterranean subdivision. J Ethnopharmacol, 39, 31-38.

13. Gong J, Xu M, Zhu C, et al (2013): Antimicrobial resistance, presence of integrons and biofilm formation of Salmonella Pullorum isolates from Eastern China (19622010). Avian Pathol, 42, 290-294.

14. Gunes H, Gulen D, Mutlu R, et al (2016): Antibacterial effects of curcumin: An in vitro minimum inhibitory concentration study. Toxicol Ind Health, 32, 246-250.

15. Gupta PD, Birdi TJ (2017): Development of botanicals to combat antibiotic resistance. J Ayurveda Integr Med, 8, 266-275.

16. Gurbuz I, Yesilada E, Demirci B, et al (2013): Characterization of volatiles and anti-ulcerogenic effect of 
Turkish sweetgum balsam (Styrax liquidus). J Ethnopharmacol, 148, 332-336.

17. Honda G, Yeşilada E, Tabata M, et al (1996): Traditional medicine in Turkey VI. Folk medicine in West Anatolia: Afyon, Kütahya, Denizli, Muğla, Aydin provinces. J Ethnopharmacol, 53, 75-87.

18. Howard ZR, O'Bryan CA, Crandall PG, et al (2012): Salmonella Enteritidis in shell eggs: Current issues and prospects for control. Food Res Int, 45, 755-764.

19. Iramiot JS, Kajumbula H, Bazira J, et al (2020): Antimicrobial resistance at the human-animal interface in the Pastoralist Communities of Kasese District, South Western Uganda. Sci Rep, 10, 14737.

20. İstek A (1995): Sı̆̆la Yağı (Storax)'nın Kimyasal Bileşenleri. Master Thesis. Graduate Institute of Natural and Applied Sciences, Trabzon.

21. Kang MS, Oh JS, Kang IC, et al (2008): Inhibitory effect of methyl gallate and gallic acid on oral bacteria. $\mathrm{J}$ Microbiol, 46, 744-750.

22. Karagoz A, Tutun H, Altintas L, et al (2020): Molecular typing of drug-resistant Mycobacterium tuberculosis strains from Turkey. J Glob Antimicrob Resist, 23, 130-134.

23. Keyvan E, Tutun H (2019): Effects of carvacrol on Staphylococcus aureus isolated from bulk tank milk. Med Weter, 75, 238-241.

24. Khameneh B, Iranshahy M, Soheili V, et al (2019): Review on plant antimicrobials: a mechanistic viewpoint. Antimicrob Resist Infect Control, 8, 118.

25. Kharat M, Du Z, Zhang G, et al (2017): Physical and Chemical Stability of Curcumin in Aqueous Solutions and Emulsions: Impact of $\mathrm{pH}$, Temperature, and Molecular Environment. J Agric Food Chem, 65, 1525-1532.

26. Kocaadam B, Sanlier N (2017): Curcumin, an active component of turmeric (Curcuma longa), and its effects on health. Crit Rev Food Sci Nutr, 57, 2889-2895.

27. Kuang X, Hao H, Dai M, et al (2015): Serotypes and antimicrobial susceptibility of Salmonella spp. isolated from farm animals in China. Front Microbiol, 6, 602-602.

28. Marathe SA, Ray S, Chakravortty D (2010): Curcumin Increases the Pathogenicity of Salmonella enterica Serovar Typhimurium in Murine Model. PLoS One, 5, e11511.

29. Marchese A, Orhan IE, Daglia M, et al (2016): Antibacterial and antifungal activities of thymol: A brief review of the literature. Food Chem, 210, 402-414.

30. Nathan C, Cars O (2014): Antibiotic resistance--problems, progress, and prospects. N Engl J Med, 371, 1761-1763.

31. Özdemir H, Keyvan E (2016): Isolation and characterisation of Staphylococcus aureus strains isolated from beef, sheep and chicken meat. Ankara Univ Vet Fak Derg, 63, 333-338.

32. Palombo EA (2011): Traditional Medicinal Plant Extracts and Natural Products with Activity against Oral Bacteria: Potential Application in the Prevention and Treatment of Oral Diseases. Evid Based Complement Alternat Med, 2011, 680354.
33. Porter JA, Morey A, Monu EA (2020): Antimicrobial efficacy of white mustard essential oil and carvacrol against Salmonella in refrigerated ground chicken. Poult Sci, 99, 5091-5095.

34. Rudramurthy GR, Swamy MK, Sinniah UR, et al (2016): Nanoparticles: Alternatives Against Drug-Resistant Pathogenic Microbes. Molecules, 21, 836.

35. Sagdic O, Ozkan G, Ozcan M, et al (2005): A study on inhibitory effects of Sigla tree (Liquidambar orientalis Mill. var. orientalis) storax against several bacteria. Phytother Res, 19, 549-551.

36. Sandikci Altunatmaz S, Yilmaz Aksu F, Issa G (2016): Antimicrobial effects of curcumin against $L$. monocytogenes, S. aureus, S. Typhimurium and E. coli O157: $H 7$ pathogens in minced meat. Vet Med (Praha), 61, 256-262.

37. Silva J, Abebe W, Sousa SM, et al (2003): Analgesic and anti-inflammatory effects of essential oils of Eucalyptus. $\mathrm{J}$ Ethnopharmacol, 89, 277-283.

38. Silva ACD, Santos PDF, Palazzi NC, et al (2017): Production and characterization of curcumin microcrystals and evaluation of the antimicrobial and sensory aspects in minimally processed carrots. Food Funct, 8, 1851-1858.

39. Stanić Z (2017): Curcumin, a Compound from Natural Sources, a True Scientific Challenge - A Review. Plant Foods Hum Nutr, 72, 1-12.

40. Tariq S, Wani S, Rasool W, et al (2019): A comprehensive review of the antibacterial, antifungal and antiviral potential of essential oils and their chemical constituents against drug-resistant microbial pathogens. Microb Pathog, 134, 103580.

41. Tutun H, Koç N, Kart A (2018): Plant essential oils used against some bee diseases. TURJAF, 6, 34-45.

42. Tyagi $\mathbf{P}$, Singh $\mathbf{M}$, Kumari $\mathbf{H}$, et al (2015): Bactericidal activity of curcumin $I$ is associated with damaging of bacterial membrane. PLoS One, 10, e0121313.

43. Ugurlu E, Secmen O (2008): Medicinal plants popularly used in the villages of Yunt Mountain(Manisa-Turkey). Fitoterapia, 79, 126-131.

44. Ultee A, Kets EP, Smid EJ (1999): Mechanisms of action of carvacrol on the food-borne pathogen Bacillus cereus. Appl Environ Microbiol, 65, 4606-4610.

45. Ultee A, Bennik MHJ, Moezelaar R (2002): The phenolic hydroxyl group of carvacrol is essential for action against the food-borne pathogen Bacillus cereus. Appl Environ Microbiol, 68, 1561-1568.

46. Wells J, Butterfield J (1999): Incidence of Salmonella on fresh fruits and vegetables affected by fungal rots or physical injury. Plant Dis, 83, 722-726.

47. White PL, Naugle AL, Jackson CR, et al (2007): Salmonella Enteritidis in meat, poultry, and pasteurized egg products regulated by the US Food Safety and Inspection Service, 1998 through 2003. J Food Prot, 70, 582-591.

48. World-Health-Organization (2021): Food safety. Available at https://www.who.int/news-room/factsheets/detail/food-safety. (Accessed January 10, 2021). 